medRxiv preprint doi: https://doi.org/10.1101/2021.03.09.21253153; this version posted March 11, 2021. The copyright holder for this preprint (which was not certified by peer review) is the author/funder, who has granted medRxiv a license to display the preprint in perpetuity.

It is made available under a CC-BY-ND 4.0 International license.

\title{
The Prognostic Value of PD-1/PD-L1 Expression on Tumor Cells and Tumor- Infiltrating Immune Cells in Patients with Colorectal Cancer: a Systematic Review and Meta-Analysis Protocol
}

\author{
Fateme Abedini $^{\text {a\# }}$, Saeedeh Salehi ${ }^{\mathrm{b} \#}$, Leila Janani ${ }^{\mathrm{c}}$, Monireh Mohsenzadegan ${ }^{\mathrm{d} *}$ \\ ${ }^{a}$ Department of Immunology, School of Medicine, Iran University of Medical Sciences, Tehran, Iran. \\ ${ }^{b}$ Department of Immunology, School of Medicine, Tehran University of Medical Sciences, Tehran, Iran. \\ ${ }^{c}$ Department of Biostatistics, School of Public Health, Iran University of Medical Sciences, Tehran, Iran. \\ ${ }^{d}$ Department of Medical Laboratory Science, Faculty of Allied Medical Sciences, Iran University of Medical \\ Sciences, Tehran, Iran.
}

* Corresponding author: Department of Medical Laboratory Science, Faculty of Allied Medical Sciences, Iran University of Medical Sciences, Tehran, Iran. Tel: +982186704681, E-mail:

monirehmohsenzadegan@gmail.com

\# These authors contributed equally.

E-mail address of authors:

Fateme.abediny@gmail.com

salehi_saeedeh@yahoo.com

leila.janani@gmail.com

$\underline{\text { monirehmohsenzadegan@gmail.com }}$

\begin{abstract}
Aim: Colorectal cancer (CRC) is one of the most common cancers in the world. However, the role of immune checkpoint molecules, especially Programmed cell death protein 1 (PD-1) and Programmed cell death-ligand 1 (PD-L1), in the progression of CRC remains unclear. This systematic review and meta-analysis will investigate the prognostic significance of PD-1/PD-L1 expression on tumorinfiltrating immune cells and tumor cells in patients with colorectal cancer.
\end{abstract}

Methods: This protocol has been prospectively registered in the PROSPERO (registration NO. CRD42020156233). A comprehensive electronic search on PubMed/MEDLINE, Scopus, Web of Science (WOS), Embase and ProQuest will be conducted using a combination of MeSH terms of "programmed cell death 1", "programmed cell death ligand 1", "colorectal" and "cancer" between 1 January 1990 and 31 March 2021 with no language limitation. Two independent reviewers will perform study selection, data extraction, and risk of bias assessment. The Newcastle-Ottawa Scale (NOS) for cohort studies will be used to assess the risk of bias. In the case of sufficient data, either random or fixed-effect models, will be used for meta-analysis. Statistical heterogeneity will be evaluated by $\chi^{2}$ test with the $\mathrm{I}^{2}$ statistic. "Funnel plot", "Begg's statistical test", and "Egger's statistical test and graph" will be used to assess publication bias. Stata V.13 software will be employed for meta-analysis.

Results and conclusion: According to the meta-analysis of the aggregated data from the relevant primary studies, the relationship between expression of PD-1/PD-L1 and prognostic parameters, including progression-free survival and gverall surviyal, will be reported. The results of the current study will be published in a peer-reviewed journal. 
medRxiv preprint doi: https://doi.org/10.1101/2021.03.09.21253153; this version posted March 11, 2021. The copyright holder for this preprint (which was not certified by peer review) is the author/funder, who has granted medRxiv a license to display the preprint in It is made available under a CC-BY-ND 4.0 International license.

\section{Introduction}

Colorectal cancer (CRC) is the second most common cancer in men and women after prostate and breast cancer, respectively. It is also the second lethal cancer after lung cancer in the world (1). The 5-year survival rate in patients with CRC is about $64 \%$. However, it relates to several factors, such as the stage of cancer, age, and overall health. For instance, $14 \%$ of people who have distant metastases have 5-year survival (2). Although the rate of death from CRC has been decreasing due to the improvement of screening and treatment, it remains a leading cause of death worldwide for its poor prognosis, especially in the late stages. Therefore, it is crucial to identify biomarkers to improve patient's outcome.

The progression of CRC is influenced by complex interactions between tumor microenvironment (TME) and tumor cells. TME employs many mechanisms to suppress the immune system (3); one of them is programmed cell death protein 1/programmed cell death-ligand 1 (PD1/PD-L1) axis, which affects the balance between immune resistance and tumor immune surveillance (4).

PD-1 (CD279) is an inhibitory co-receptor expressed on the surface of activated immune cells, including dendritic cells, macrophages, natural killer (NK) cells, and tumor-infiltrating lymphocytes (TILs; e.g., T cells, and B cells) (5). PD-L1 (CD274) - the primary ligand of PD-1 - is expressed by the immune system or cancer cells (6). Immune cells, such as activated lymphocytes (T, B, and NK cells) express PD-L1 on their surface (3). The high expression of PD-L1 on TILs or tumor cells leads to $\mathrm{T}$ cell exhaustion and promotes tumor progression (4).

The interaction between PD-1 and PD-L1 sends inhibitory signals that block the production of cytotoxic mediators required for the killing of tumor cells and also reduces the proliferation of $\mathrm{T}$ cells $(7,8)$.

The relation between unusual expression of PD-L1 and prognosis or response to the treatment has been observed in several cancers. For example, the relationship between PD-L1 expression and prognosis has been detected in different solid tumors, including urothelial carcinoma, non-small cell 
medRxiv preprint doi: https://doi.org/10.1101/2021.03.09.21253153; this version posted March 11, 2021. The copyright holder for this preprint (which was not certified by peer review) is the author/funder, who has granted medRxiv a license to display the preprint in It is made available under a CC-BY-ND 4.0 International license.

lung cancer (NSCLC), and ovarian cancer (9-11). Furthermore, several studies have investigated the relationship between the expression of PD-1/PD-L1 and survival in patients with CRC; some of them have shown that patients with overexpression of these molecules have better survival than others (12, 13), but other studies have illustrated opposite results or no relationship $(14,15)$.

Due to these controversies, several systematic reviews and meta-analyses have been conducted in order to evaluate the prognostic significance of PD-L1 expression in patients with CRC and other cancers. Two meta-analyses have been done in all of the cancers and showed the PD-L1 expression is linked to a poor prognosis $(16,17)$. Another meta-analysis has evaluated the prognostic significance of PD-1 and PD-L1 expressions in immune cells of the tumor microenvironment and showed the prognostic role of these molecules in the cancers (18). Four studies in 2018 and 2019, have examined the relationship between PD-L1 expression on tumor cells and prognostic parameters in patients with $\mathrm{CRC}$ and concluded that PD-L1 overexpression is related to a poor prognosis (1922). Most of these studies consist of English-language articles only; and focused on the expression of PD-L1 on tumor cells.

This systematic review and meta-analysis aims to evaluate the association between PD-1/PDL1 expression on both tumor cells and TIICs and prognostic parameters (e.g., overall survival (OS), progression-free survival (PFS), disease-free survival (DFS), and recurrent-free survival (RFS)) in patients with colorectal cancer. The secondary objective is about evaluating the relationship between PD-1/PD-L1 expression and clinicopathological features (e.g., stage of cancer, tumor location, microsatellite stability status, differentiation grade, vascular or lymphatic invasion).

Based on our knowledge, this study, for the first time, will simultaneously evaluate the association between the expression of both PD-1 and PD-L1 on both tumor cells and TIICs and compare their expression with prognostic parameters in patients with CRC. Moreover, no restriction on publication language will be applied to this study. 
medRxiv preprint doi: https://doi.org/10.1101/2021.03.09.21253153; this version posted March 11, 2021. The copyright holder for this preprint (which was not certified by peer review) is the author/funder, who has granted medRxiv a license to display the preprint in It is made available under a CC-BY-ND 4.0 International license

\section{Methods}

This protocol has been prospectively registered in the PROSPERO International prospective register of systematic reviews (registration NO. CRD42020156233). The methods adopted for this review conform to Preferred Reporting Items for Systematic Review and Meta-Analysis (PRISMA) checklist for systematic reviews (23), and the protocol has been adopted to the PRISMA-P 2015 checklist (supplemental file 1) (24). Furthermore, the number of included or excluded original studies during the study selection will be described through the PRISMA flow diagram (figure 1) (23).

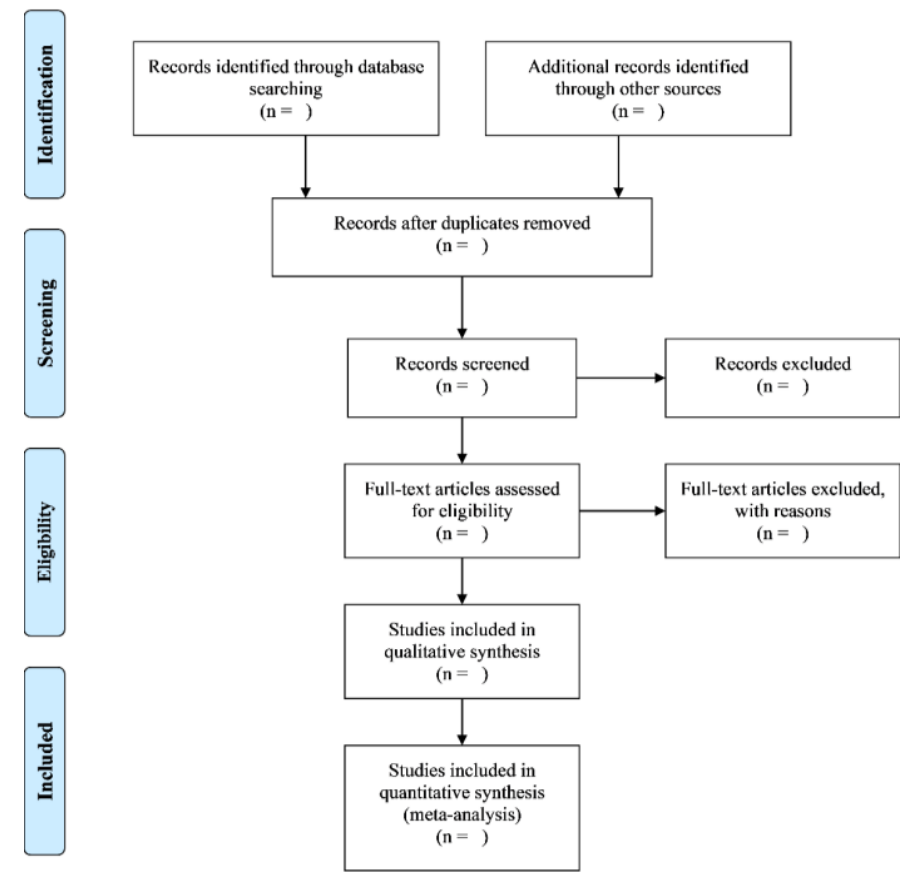

Figure 1. PRISMA flow diagram

\subsection{Inclusion and exclusion criteria}

\section{Study characteristics}

(1) Only cohort studies will be included in this study.

(2) There is no restriction on the language of studies (Google Translate will be used to translate non-English articles appropriately).

(3) There is no geographic limitation for the studies. 
medRxiv preprint doi: https://doi.org/10.1101/2021.03.09.21253153; this version posted March 11, 2021. The copyright holder for this preprint (which was not certified by peer review) is the author/funder, who has granted medRxiv a license to display the preprint in It is made available under a CC-BY-ND 4.0 International license.

(4) Case reports, case series, letters, review articles, and experimental studies will be excluded.

\section{Participant characteristics}

(1) All patients histologically confirmed as having CRC and also had been undergone surgery without preoperative treatment will be included.

(2) Patients with sporadic CRC will be included, and patients with hereditary CRC (Lynch syndrome or non-polyposis colon cancer) will be excluded.

(3) Studies with any age groups, sexes, and races will be included.

(4) All stages of cancer will be included.

\section{Exposure}

(5) Only studies evaluated PD-1 or PD-L1 expression by immunohistochemistry (IHC) will be included.

(6) Studies with any cut-off values of PD-1 or PD-L1 expression will be included.

\section{Outcome}

(7) Studies that showed an association between expression of PD-1 or PD-L1 and prognosis (i.e., OS, PFS, DFS, RFS) will be included.

(8) Studies that presented a hazard ratio (HR) with its confidence interval (CI) or adequate data to assess survival parameters will be included.

\subsection{Search strategy}

Electronic databases such as PubMed/MEDLINE, Scopus, Embase, and Web of Science (WoS) will be searched between 1 January 1990 and 31 March 2021 (The search time interval was extended). The search syntax has been combined of MeSH terms, Emtree terms, and free text words of "programmed cell death 1", "programmed cell death ligand 1", "colorectal" and "cancer" and their 
medRxiv preprint doi: https://doi.org/10.1101/2021.03.09.21253153; this version posted March 11, 2021. The copyright holder for this preprint (which was not certified by peer review) is the author/funder, who has granted medRxiv a license to display the preprint in It is made available under a CC-BY-ND 4.0 International license.

equivalents. The syntax will be developed in PubMed and adopted for other databases.

\section{Other resources}

Google Scholar will be searched to find additional relevant studies; furthermore, gray literature, including conference papers and the thesis, will be searched. ProQuest database will also be searched for the relevant thesis. Moreover, key journals and also reference lists of included researches will be manually searched for relevant references.

\subsection{Data collection and analysis}

All the records from all databases will be imported to the EndNote X8 software, and duplicated researches will be removed from the library.

\section{Study selection}

Two reviewers independently will screen all the records attained from the search strategy through titles and abstracts for choosing eligible studies. Afterward, they will independently assess the full text of selected articles at the previous step, according to the eligibility criteria to include relevant studies. The reviewers will discuss to resolve the disagreements, and when it is not attained, a third reviewer will act as a referee.

\section{Data extraction}

The required data will be independently extracted from original articles by two reviewers. Discrepancies will be resolved by consensus, and when it is not achieved, a third reviewer will act as a referee and decide which data should be entered. The required data for extraction from the included studies, are listed below: 
medRxiv preprint doi: https://doi.org/10.1101/2021.03.09.21253153; this version posted March 11, 2021. The copyright holder for this preprint (which was not certified by peer review) is the author/funder, who has granted medRxiv a license to display the preprint in It is made available under a CC-BY-ND 4.0 International license.

1. Study characteristics: First author's name, year of publication, the country which study was performed, sample size, and follow-up duration.

2. participants characteristics: Age, gender, stage of cancer, tumor location (right colon, left colon and rectum), microsatellite stability status, differentiation grade (poorly differentiated/ undifferentiated or moderately/ well-differentiated), vascular invasion status, lymphatic invasion status, and type of postoperative treatment (chemotherapy or chemoradiotherapy).

3. Exposure details: Tissue sampling (tissue microarray or whole section), type of antibody used for IHC (monoclonal or polyclonal antibody), cut-off values (for PD-1 and PD-L1 expression), type of cells which express PD-1/PD-L1 (tumor-infiltrating immune cells or tumor cells), the measurement method of mismatch repair deficiency (dMMR) (i.e., IHC, PCR, etc.).

4. Outcome measures: Outcome parameters (OS, PFS, DFS, and RFS), the HRs and their 95\% CIs of outcome parameters, the risk ratio (RR) of the relationship between PD-1/PD-L1 expression and clinicopathological characteristics and its $95 \% \mathrm{CI}$.

\section{Dealing with data in special conditions}

In the case of missing necessary data, we will send the email three times in two weeks to the corresponding authors of the eligible studies for explaining the aim of the review and requesting their data. If we do not receive any response, we will try to extract the data from survival curves with WebPlotDigitizer version 4.2 (25); and when it is not possible, we will exclude the study. If one study has multiple publications, we will use the complete version of it.

\section{Risk of bias assessment}

Two assessors will assess the risk of bias independently, according to the Newcastle-Ottawa Scale (NOS) for cohort studies, which has three domains: selection (4 items), comparability (1 item), and 
medRxiv preprint doi: https://doi.org/10.1101/2021.03.09.21253153; this version posted March 11, 2021. The copyright holder for this preprint (which was not certified by peer review) is the author/funder, who has granted medRxiv a license to display the preprint in It is made available under a CC-BY-ND 4.0 International license.

outcome (3 items). Questions that receive a star will calculate in the final score $(26,27)$. Conflicts between the assessors will be resolved by consensus, and if it is not possible, a third assessor will act as an arbitrator.

\subsection{Statistical analysis and data synthesis}

All analyses will be performed on the aggregated data extracted from primary studies using Stata software version 13 (StataCorp LP, College Station, Tx, USA). The meta-analysis will be used to assess the prognostic significance of PD-1/PD-L1 expression in patients with CRC. If there is a sufficient number of primary studies, meta-analysis will be conducted, and if it is not applicable, meta-synthesis may be applied. According to the study conditions, either the random effect model (REM) or fixed effect model (FEM) will be used. Time-to-event (survival) data will be analyzed using the HR measure with its $95 \%$ CI. Besides, the RR measure with its $95 \%$ CI, will be used to analyze dichotomous data. Moreover, forest plots will be utilized to present the data from the metaanalyses. A $P$-value $\leq 0.05$ will be considered as statistical significance.

\section{Assessment of heterogeneity}

Statistical heterogeneity will be assessed by Cochran's Q $\left(\chi^{2}\right)$ test with related P-value, and the $\mathrm{I}^{2}$ statistic as recommended by the Cochrane Handbook for Systematic Reviews of Interventions (28). The $\mathrm{I}^{2}$ statistic will be interpreted by the following guide (29):

- "0\% to 40\%: not important;

- $30 \%$ to $60 \%$ : moderate heterogeneity;

- $50 \%$ to $90 \%$ : substantial heterogeneity;

- $75 \%$ to $100 \%$ : considerable heterogeneity." 
medRxiv preprint doi: https://doi.org/10.1101/2021.03.09.21253153; this version posted March 11, 2021. The copyright holder for this preprint (which was not certified by peer review) is the author/funder, who has granted medRxiv a license to display the preprint in It is made available under a CC-BY-ND 4.0 International license.

In the case of considerable heterogeneity $\left(\mathrm{I}^{2}>75 \%\right)$, either subgroup analysis or metaregression will be conducted. Likely sources of heterogeneity would be tissue sampling, follow-up period, PD-1/PD-L1 cut-off point, country, and quality of studies.

\section{Assessment of publication bias}

Publication bias will be assessed by "funnel plot", "Begg's statistical test" and "Egger's statistical test and graph" $(30,31)$. If the above methods show evidence of publication bias, the "Trim and Fill method" $(32,33)$ will be used to correct the effect. A $P \leq 0.05$ will be defined as statistical significance.

Sensitivity analysis

Sensitivity analysis will be performed by One-study remove (leave-one-out) method. If one of the combinations shows different results from others, the characteristics of that study will be accurately assessed.

\section{Results}

This is an on-going study, and according to the meta-analysis of the aggregated data from the relevant primary studies, the association between PD-1/PD-L1 expression and prognostic parameters (such as OS and DFS) will be reported.

\section{Discussion}

PD-1 and PD-L1 are two immune checkpoint molecules that regulate immune responses. According to the role of these molecules in suppressing the immune system, several studies have been performed to evaluate the prognostic significance of these markers in various types of cancers $(10,11,34)$. However, there is controversy on the prognostic role of PD-1 and PD-L1 in patients with CRC (1215). In the current systematic review and meta-analysis, we will comprehensively search the 
medRxiv preprint doi: https://doi.org/10.1101/2021.03.09.21253153; this version posted March 11, 2021. The copyright holder for this preprint (which was not certified by peer review) is the author/funder, who has granted medRxiv a license to display the preprint in It is made available under a CC-BY-ND 4.0 International license.

databases and pool the aggregated data to evaluate the prognostic impact of PD-1 and PD-L1 in CRC. The results of this study will be published in a peer-reviewed journal.

The strengths of this study are: prospectively protocol registration, searching ProQuest database, searching gray literature and key journals, and no limitation in the language of studies.

\section{Author contribution}

FA and SS designed the study, prepared the draft of the protocol, and developed the search syntax. LJ and MM revised the manuscript. Screening and selection of the primary studies will be done by FA and SS under the guidance of MM. Data extraction will be done by FA and HB under the supervision of MM. The risk of bias will be assessed by FA and AKh under the superintendence of LJ. LJ also will analyze the data extracted from the included studies. All the authors will revise the final version of the manuscript before the publication.

\section{Disclosure of interest}

The authors report no conflict of interest.

\section{Funding}

This work was supported by the Iran University of Medical Sciences under Grant (99-1-4-17381).

\section{References}

1. Bray F., Ferlay J., Soerjomataram I., Siegel R. L., Torre L. A., Jemal A. Global cancer statistics 2018: GLOBOCAN estimates of incidence and mortality worldwide for 36 cancers in 185 countries. CA Cancer J Clin. 2018;68(6):394-424. doi: 10.3322/caac.21492. PubMed PMID: 30207593.

2. Siegel R. L., Miller K. D., Jemal A. Cancer statistics, 2020. CA Cancer J Clin. 2020;70(1):7-30. doi: 10.3322/caac.21590. PubMed PMID: 31912902. 
medRxiv preprint doi: https://doi.org/10.1101/2021.03.09.21253153; this version posted March 11, 2021. The copyright holder for this preprint (which was not certified by peer review) is the author/funder, who has granted medRxiv a license to display the preprint in It is made available under a CC-BY-ND 4.0 International license.

3. Passardi A., Canale M., Valgiusti M., Ulivi P. Immune Checkpoints as a Target for Colorectal Cancer Treatment. Int J Mol Sci. 2017;18(6). doi: 10.3390/ijms18061324. PubMed PMID: 28635639.

4. Yi M., Jiao D., Xu H., Liu Q., Zhao W., Han X., Wu K. Biomarkers for predicting efficacy of PD-1/PD-L1 inhibitors. Mol Cancer. 2018;17(1):129. doi: 10.1186/s12943-018-0864-3. PubMed PMID: 30139382.

5. $\quad$ Dong Y., Sun Q., Zhang X. PD-1 and its ligands are important immune checkpoints in cancer. Oncotarget. 2017;8(2):2171-2186. doi: 10.18632/oncotarget.13895. PubMed PMID: 27974689.

6. Xu-Monette Z. Y., Zhang M., Li J., Young K. H. PD-1/PD-L1 Blockade: Have We Found the Key to Unleash the Antitumor Immune Response? Front Immunol. 2017;8:1597. doi: 10.3389/fimmu.2017.01597. PubMed PMID: 29255458.

7. Chen D. S., Irving B. A., Hodi F. S. Molecular pathways: next-generation immunotherapy-inhibiting programmed death-ligand 1 and programmed death-1. Clin Cancer Res. 2012;18(24):6580-6587. doi: 10.1158/1078-0432.ccr-12-1362. PubMed PMID: 23087408.

8. Chen D. S., Mellman I. Oncology meets immunology: the cancer-immunity cycle. Immunity. 2013;39(1):1-10. doi: 10.1016/j.immuni.2013.07.012. PubMed PMID: 23890059. 9. Miyama Y., Morikawa T., Miyakawa J., Koyama Y., Kawai T., Kume H., Fukayama M. The prognostic value of PD-L1 expression in upper tract urothelial carcinoma varies according to platelet count. Cancer Med. 2018;7(9):4330-4338. doi: 10.1002/cam4.1686. PubMed PMID: 30062756.

10. Schmidt L. H., Kümmel A., Görlich D., Mohr M., Bröckling S., Mikesch J. H., Grünewald I., Marra A., Schultheis A. M., Wardelmann E., et al. PD-1 and PD-L1 Expression in NSCLC Indicate a Favorable Prognosis in Defined Subgroups. PLoS One. 2015;10(8):e0136023. doi: 10.1371/journal.pone.0136023. PubMed PMID: 26313362. 
medRxiv preprint doi: https://doi.org/10.1101/2021.03.09.21253153; this version posted March 11, 2021. The copyright holder for this preprint (which was not certified by peer review) is the author/funder, who has granted medRxiv a license to display the preprint in It is made available under a CC-BY-ND 4.0 International license.

11. Darb-Esfahani S., Kunze C. A., Kulbe H., Sehouli J., Wienert S., Lindner J., Budczies J., Bockmayr M., Dietel M., Denkert C., et al. Prognostic impact of programmed cell death-1 (PD-1) and PD-ligand 1 (PD-L1) expression in cancer cells and tumor-infiltrating lymphocytes in ovarian high grade serous carcinoma. Oncotarget. 2016;7(2):1486-1499. doi: 10.18632/oncotarget.6429. PubMed PMID: 26625204.

12. $\quad$ Wei X. L., Wu Q. N., Chen D. L., Zeng Z. L., Lu J. B., Liu Z. X., Ju H. Q., Ren C., Pan Z. Z., Wang F. H., et al. The Clinical and Biomarker Association of Programmed Death Ligand 1 and its Spatial Heterogeneous Expression in Colorectal Cancer. J Cancer. 2018;9(23):4325-4333. doi: 10.7150/jca.27735. PubMed PMID: 30519336.

13. Li Y., Liang L., Dai W., Cai G., Xu Y., Li X., Li Q., Cai S. Prognostic impact of programed cell death-1 (PD-1) and PD-ligand 1 (PD-L1) expression in cancer cells and tumor infiltrating lymphocytes in colorectal cancer. Mol Cancer. 2016;15(1):55. doi: 10.1186/s12943-016-0539-x. PubMed PMID: 27552968.

14. Enkhbat T., Nishi M., Takasu C., Yoshikawa K., Jun H., Tokunaga T., Kashihara H., Ishikawa D., Shimada M. Programmed Cell Death Ligand 1 Expression Is an Independent Prognostic Factor in Colorectal Cancer. Anticancer Res. 2018;38(6):3367-3373. doi: 10.21873/anticanres.12603. PubMed PMID: 29848685.

15. Li P., Huang T., Zou Q., Liu D., Wang Y., Tan X., Wei Y., Qiu H. FGFR2 Promotes Expression of PD-L1 in Colorectal Cancer via the JAK/STAT3 Signaling Pathway. J Immunol. 2019;202(10):3065-3075. doi: 10.4049/jimmunol.1801199. PubMed PMID: 30979816.

16. Wu P., Wu D., Li L., Chai Y., Huang J. PD-L1 and Survival in Solid Tumors: A MetaAnalysis. PLoS One. 2015;10(6):e0131403. doi: 10.1371/journal.pone.0131403. PubMed PMID: 26114883.

17. Pyo J. S., Kang G., Kim J. Y. Prognostic role of PD-L1 in malignant solid tumors: a metaanalysis. Int J Biol Markers. 2017;32(1):e68-e74. doi: 10.5301/jbm.5000225. PubMed PMID: 27470134. 
medRxiv preprint doi: https://doi.org/10.1101/2021.03.09.21253153; this version posted March 11, 2021. The copyright holder for this preprint (which was not certified by peer review) is the author/funder, who has granted medRxiv a license to display the preprint in It is made available under a CC-BY-ND 4.0 International license.

18. Kim Y., Wen X., Cho N. Y., Kang G. H. Intratumoral immune cells expressing PD-1/PD-L1 and their prognostic implications in cancer: a meta-analysis. Int J Biol Markers.

2018:1724600818770941. doi: 10.1177/1724600818770941. PubMed PMID: 29779430.

19. Yang L., Xue R., Pan C. Prognostic and clinicopathological value of PD-L1 in colorectal cancer: a systematic review and meta-analysis. Onco Targets Ther. 2019;12:3671-3682. doi: 10.2147/OTT.S190168. PubMed PMID: 31190869.

20. Shen Z., Gu L., Mao D., Chen M., Jin R. Clinicopathological and prognostic significance of PD-L1 expression in colorectal cancer: a systematic review and meta-analysis. World J Surg Oncol. 2019;17(1):4. doi: 10.1186/s12957-018-1544-x. PubMed PMID: 30609938.

21. Li Y., He M., Zhou Y., Yang C., Wei S., Bian X., Christopher O., Xie L. The Prognostic and Clinicopathological Roles of PD-L1 Expression in Colorectal Cancer: A Systematic Review and Meta-Analysis. Front Pharmacol. 2019;10:139. doi: 10.3389/fphar.2019.00139. PubMed PMID: 30873025.

22. Ni X., Sun X., Wang D., Chen Y., Zhang Y., Li W., Wang L., Suo J. The clinicopathological and prognostic value of programmed death-ligand 1 in colorectal cancer: a meta-analysis. Clin Transl Oncol. 2018. doi: 10.1007/s12094-018-1970-9. PubMed PMID: 30392153.

23. Moher D., Liberati A., Tetzlaff J., Altman D. G. Preferred reporting items for systematic reviews and meta-analyses: the PRISMA statement. PLoS Med. 2009;6(7):e1000097. doi: 10.1371/journal.pmed.1000097. PubMed PMID: 19621072.

24. Shamseer L., Moher D., Clarke M., Ghersi D., Liberati A., Petticrew M., Shekelle P., Stewart L. A., Group Prisma- P. Preferred reporting items for systematic review and meta-analysis protocols (PRISMA-P) 2015: elaboration and explanation. BMJ. 2015;350:g7647. doi: 10.1136/bmj.g7647. PubMed PMID: 25555855.

25. Rohatgi A. WebPlotDigitizer [updated 2019 April; accessed 2019 Sep 1]. version 4.2. https://automeris.io/WebPlotDigitizer. 
medRxiv preprint doi: https://doi.org/10.1101/2021.03.09.21253153; this version posted March 11, 2021. The copyright holder for this preprint (which was not certified by peer review) is the author/funder, who has granted medRxiv a license to display the preprint in It is made available under a CC-BY-ND 4.0 International license.

26. Wells G, Shea B, O’Connell D, Peterson J, Welch V, Losos M, Tugwell P. The NewcastleOttawa Scale (NOS) for assessing the quality of nonrandomised studies in meta-analyses [accessed 2019 Sep 1]. http://www.ohri.ca/programs/clinical_epidemiology/oxford.asp.

27. Wells G, Shea B, O’Connell D, Peterson J, Welch V, Losos M, Tugwell P. NewcastleOttawa quality assessment scale cohort studies. 2014.

28. Higgins JP, S Green. Cochrane Handbook for Systematic Reviews of Interventions: Wiley Online Library; 2012.

29. Deeks J, Higgins J, D Altman. In: Higgins JPT GS, editor. Cochrane handbook for systematic reviews: Wiley-Blackwell; 2012. p. 243-296.

30. Egger M., Davey Smith G., Schneider M., Minder C. Bias in meta-analysis detected by a simple, graphical test. Bmj. 1997;315(7109):629-634. doi: 10.1136/bmj.315.7109.629. PubMed PMID: 9310563.

31. Begg C. B., Mazumdar M. Operating characteristics of a rank correlation test for publication bias. Biometrics. 1994;50(4):1088-1101. doi: 10.2307/2533446. PubMed PMID: 7786990.

32. Duval S., Tweedie R. A Nonparametric “Trim and Fill” Method of Accounting for Publication Bias in Meta-Analysis. Journal of the American Statistical Association. 2000;95(449):89-98. doi: 10.1080/01621459.2000.10473905.

33. Duval S., Tweedie R. Trim and fill: A simple funnel-plot-based method of testing and adjusting for publication bias in meta-analysis. Biometrics. 2000;56(2):455-463. doi: 10.1111/j.0006-341x.2000.00455.x. PubMed PMID: 10877304.

34. Kiyasu J., Miyoshi H., Hirata A., Arakawa F., Ichikawa A., Niino D., Sugita Y., Yufu Y., Choi I., Abe Y., et al. Expression of programmed cell death ligand 1 is associated with poor overall survival in patients with diffuse large B-cell lymphoma. Blood. 2015;126(19):2193-2201. doi: 10.1182/blood-2015-02-629600. PubMed PMID: 26239088. 